\title{
Preliminar results of paleontological salvage at Belo Monte Powerplant construction
}

\author{
Tomassi, HZ. ${ }^{*}$, Almeida, CM. ${ }^{a, b}$, Ferreira, BC. ${ }^{a}$, Brito, MB. ${ }^{a}$, Barberi, M. ${ }^{c}$, Rodrigues, GC. ${ }^{c}$, \\ Teixeira, SP. ${ }^{c}$, Capuzzo, JP. ${ }^{c}$, Gama-Júnior, JM. ${ }^{a}$ and Santos, MGKG. ${ }^{a}$

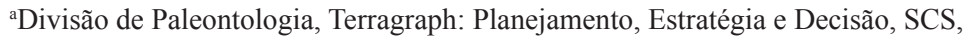 \\ Quadra 2, Bloco D, Edifício Oscar Niemeyer, CEP 70316-900, Brasília, DF, Brazil

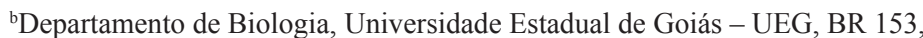 \\ Km 98, CEP 75001-970, Anápolis, GO, Brazil

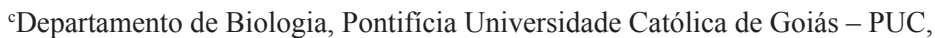 \\ Avenida Universitária, 1440, Setor Universitário, CEP 74605-900, Goiânia, GO, Brazil \\ *e-mail: HZTomassi@gmail.com
}

Received: June 2, 2014 - Accepted: April 29, 2015 - Distributed: August 31, 2015

(With 9 figures)

\begin{abstract}
In this paper some preliminary fossil specimens are presented. They represent a collection sampled by Belo Monte's Programa de Salvamento do Patrimônio Paleontológico (PSPP), which includes unprecedented invertebrate fauna and fossil vertebrates from Pitinga, Jatapu, Manacapuru, Maecuru e Alter do Chão formations from Amazonas basin, Brazil. The Belo Monte paleontological salvage was able to recover 495 microfossil samples and 1744 macrofossil samples on 30 months of sampling activities, and it is still ongoing. The macrofossils identified are possible plant remains, ichnofossils, graptolites, brachiopods, molluscs, athropods, Agnatha, palynomorphs (miosphores, acritarchs, algae cysts, fungi spores and unidentified types) and unidentified fossils. However, deep scientific research is not part of the scope of the program, and this collection must be further studied by researchers who visit Museu Paraense Emilio Goeldi, where the fossils will be housed. More material will be collected until the end of the program. The collection sampled allows a mosaic composition with the necessary elements to assign, in later papers, taxonomic features which may lead to accurate species identification and palaeoenvironmental interpretations.
\end{abstract}

Keywords: mitigation paleontology, Silurian, Devonian, cretaceous, South America, Southern Hemisphere.

\section{Resultados preliminares do programa de salvamento paleontológico da construção da Hidrelétrica de Belo Monte}

\section{Resumo}

Neste artigo são apresentados de forma preliminar alguns espécimes fósseis representativos do acervo coletado no Programa de Salvamento do Patrimônio Paleontológico (PSPP) da UHE Belo Monte, que inclui fauna vertebrada e invertebrada inédita das formações Pitinga, Jatapu, Manacapuru, Maecuru e Alter do Chão, da bacia do Amazonas, Brasil. No salvamento paleontológico de Belo Monte foi possível recuperar 495 amostras para microfósseis e 1744 amostras com macrofósseis em 30 meses de amostragem, que ainda continua em andamento. Os macrofósseis identificados são possíveis restos de plantas, icnofósseis, graptolitos, braquiópodes, moluscos, artópodes, Agnatha, palinomorfos (miósporos, acritarcas, cistos de alga, esporos de fungo e tipos indeterminados) além de fósseis não identificados. No entanto, pesquisa científica aprofundada não é parte do escopo do programa, e esta coleção deve ser estudada no futuro por pesquisadores pela visita ao Museu Paraense Emilio Goeldi, onde os fósseis ficarão depositados. Mais material será coletado até o fim de 2015. A assemblagem coletada permite a composição de mosaico com elementos necessários para a definição, em artigos futuros, características taxonômicas que levarão à identificação precisa de espécies e interpretações paleoambientais.

Palavras-chave: resgate paleontológico, Siluriano, Devoniano, cretáceo, América do Sul, Hemisfério Sul.

\section{Introduction}

Paleontological salvage programs are relatively new on Brazilian territory. Just a few programs on that matter were carried to the moment, on which it is possible to highlight the mitigation paleontology at Estreito powerplant building, at Tocantins and Maranhão states boundary, and at Jirau and Santo Antônio powerplant building, Rondônia State. 
The Belo Monte paleontological salvage was sought by the governmental organ responsible by fossil patrimony protection, the Departamento Nacional de Produção Mineral (DNPM). The execution request of the program titled Programa de Salvamento do Patrimônio Paleontológico (PSPP) was made thru the document 125/2010, from DNPM addressed to Norte Energia S.A. the company responsible by the hydroelectric powerplant construction.

The main objective of Belo Monte PSPP is the preventive fossil sampling in the areas in which Amazonas basin rocks are excavated, moved or flooded and also to carry patrimonial educational activities at Belo Monte surroundings. The program is developed by Terragraph Paleontologia for Norte Energia S.A. and is needed due to the earthworks, the continuous exposition of potentially fossiliferous rocks at construction sites and other places affected by the construction of the hydroelectric powerplant, on the Vitória do Xingu and Altamira municipalities, Pará State.

Following DNPM instructions, three areas were created for PSPP operation. The first include the flood and dams construction areas at Sítio Belo Monte, the second encompass areas with sedimentary rocks to be flooded at Xingu margins near Altamira City and the third includes the attendance of redesign and pavement works of Travessão 27 , which is an important access road to construction sites south of Sítio Belo Monte (see Figure 1).

The opportunity of sampling in such a huge construction site is very important and is also an unique occasion when considering that natural rock outcrops are rare on the Amazon forest, were chemical weathering is intense and soil profiles deep.

Initiated at july 2011 and still ongoing, PSPP regularly monitor the construction progress and executes the exhaustive sampling of all fossil groups which occur at the areas defined for attendance. Later the samples and all associated geologic information which includes a detailed geologic map and correlated stratigraphic columns will be shipped to Museu Paraense Emílio Goeldi, which is a public safeguard institution chosen by its proximity with the samples provenance location, at Pará State, and also by its good tradition on the curator of fossil specimens.
The objective of this article is to preliminarily present the collection sampled at PSPP scope in order to illustrate the diversity of the collection produced by it and to publicize this material which presents high potential for paleontological research. Further details are described on unpublished technical reports submitted to Norte Energia S.A. (2011) and DNPM.

Our goal is to make an exhaustive sampling of as many fossils as possible because engineering excavations at construction sites are fast made and buried and the paleontological team must always promptly work on those places to avoid fossil lost. That's why the presented taxonomy is also preliminary, as we did not putted too much effort on taxonomic research, which is more appropriate to be made later. All the material collected will be at the disposal of the scientific community for future studies, at a safeguard institution.

\subsection{Geologic setting}

In the northern portion of the South American continent the large Amazonas, Solimões and Parnaíba intracratonic syneclises were formed. The sedimentary fill of syneclises cover a large spatial and temporal variation, since their deposits are wide and distributed in truly continental scale, covering ages from Proterozoic to the Recent. The Amazonas basin has an area of approximately 500,000 square kilometers. It reaches parts of Brazilian Amazonas and Pará states of and is separated from the eastern Marajo basin by the Gurupá Arch, and west of the Solimões basin by the Purus Arch (Cunha et al., 2007).

The stratigraphic framework of Amazonas basin, considering the premises of sequence stratigraphy, has two first order major sequences, totaling approximately 5,000 meters of sedimentary and igneous fill. They are: a Paleozoic, consisting of sedimentary rocks of varying nature, associated with a large volume of dykes and sills intrusions of Mesozoic diabase and Mesozoic-Cenozoic sedimentary units. The Paleozoic major sequence, according to the same criteria, can be divided into four sequences, formally designated as Ordovician-Devonian sequences, Devonian-Tournaisian, Neovisean and Pennsylvanian-Permian

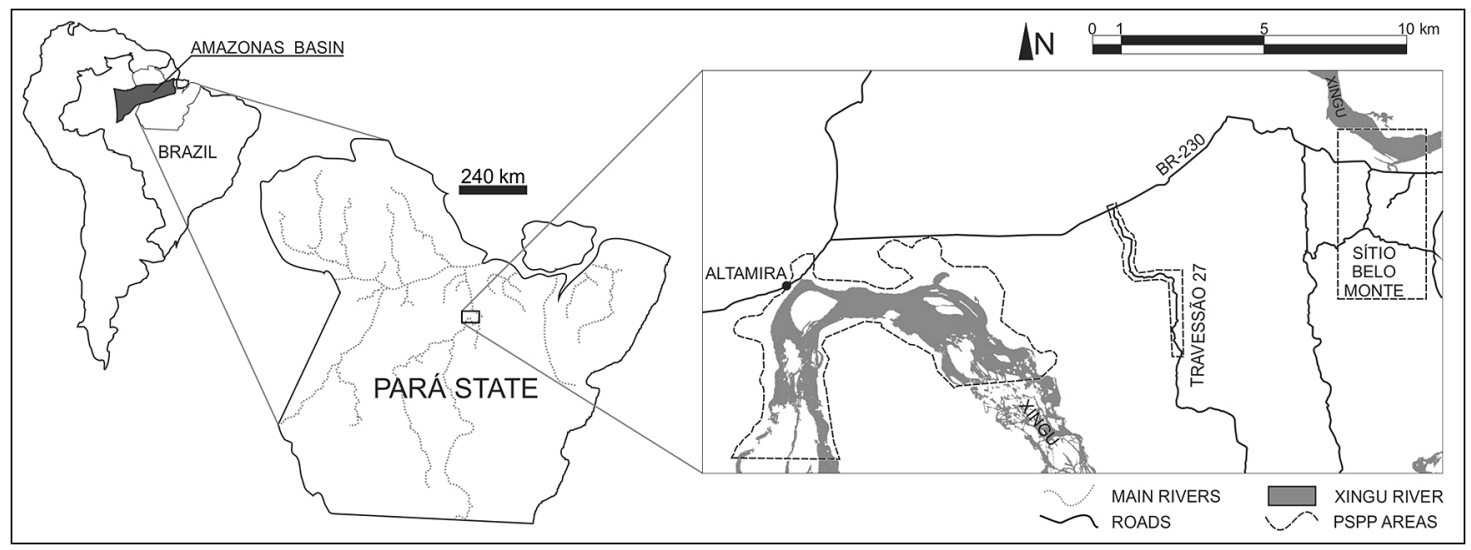

Figure 1. Location map of PSPP monitoring areas, Pará State, Brazil. 
(Cunha et al., 2007). All these sequences are bounded by significant sedimentation breaks resulted from active tectonic events on the edges of the Gondwanan plate, portrayed by significant regional unconformity which separates it.

\subsection{Description and palaeontology of geological units at Belo Monte}

Five geological formations can be found at Belo Monte surroundings: Pitinga, Manacapuru, Jatapu, Maecuru and Alter do Chão. The Pitinga Formation consists of shales and diamictites (Cunha et al., 2007). There are fossiliferous levels of fine sandstone with cross beds and hummocky, with the classical invertebrate fauna (mollusks and brachiopods) described by Clarke (1899). As for microfossils, the lower subunit, is dated the Llandovery-Eowenlock (and-Silurian) based on Chitinozoa (Grahn, 2005, 2006). The top subunit is currently dated as Ludlow-Eopridoli (neo-Silurian) based in Chitinozoa and miospores (Grahn, 2005, 2006; Steemans et al., 2008.). The macrofossils are represented by molluscs and brachiopods (Clarke, 1899). Based on the paleontological assemblage, Pitinga Formation has its stratigraphic range considered within Middle Llandovery-Lower Pridoli (Silurian). The depositional environment is interpreted as a marine distal neritic paleoenvironment (lower portion) and deltaic (upper portion; Cunha et al., 2007).

The Manacapuru Formation consists of sandstones and predominantly sandy mudstones (Cunha et al., 2007). The records of microfossils are characterized by the presence of Chitinozoa and miospores (Grahn and Melo, 1990, 2004; Grahn, 2005). The macrofossils recovered are represented by Acanthodii (fin spines, teeth, scales and dermal plates; Janvier and Melo, 1988, 1992) and Chondrichthyes (spines of fins) these records are the most ancient occurrences for vertebrates on Brazil. As for invertebrates, there are brachiopods, Conularia and trace fossils (Wanderley Filho et al., 2005). Based on fossil content recovered in this stratigraphic unit it is possible to infer a shallow marine paleoenvironment for it (Cunha et al., 2007). Nowadays the age of this stratigraphic unit is considered Lower Ludlow-Upper Lochkovian (Neosilurian-Eodevonian) (Grahn and Melo, 1990, 2004; Grahn, 2005; Cunha et al., 2007; Steemans et al., 2008).

The Jatapu Formation is characterized by fine to medium sandstones, siltstones and micaceous bioturbated shales with some hematitic levels that goes to progradational deltaic tide-dominated deposits. The miospore and chitinozoans are common at this unit, and macrofossils are apparently absent on it. The Jatapu beds were deposited at a shallow transgressive marine palaeoenvironment ot its base gradating to deltaic fronts and off-shore mudstones towards the central axis of the basin. The age is Lochkovian-Eoemsian (Eodevonian) based on palynmorphs (Cunha et al., 2007).

The lithology of Maecuru Formation consists predominantly of sandstones and mudstones. The sandstones are fine to coarse, ferruginous, bioturbated and fossiliferous, can also be silicified. There are some mudstones and subordinated cherts. Microfossil occurrences of in this formation consist of miospores and chitinozoa (Melo and Loboziak, 2003; Grahn and Melo, 2004; Cunha et al., 2007). The macropaleontological record in this formation is represented by brachiopods, trilobites, molluscs, gastropods, crinoids, bryozoans, belerofontids, cnidarians, tentaculids and conularia (Ponciano et al., 2007a, 2007b; Ponciano and Machado, 2007a, 2007b; Ponciano et al., 2008; Ponciano, 2010). The paleoenvironment is interpreted as marine neritic to deltaic (Cunha et al., 2007). It occurs in almost the entire basin, including cropping out in the northern and southern borders, having fluviodeltaic facies on the borders, going for thin estuarine facies, shoreface and barrier islands dominated by waves, toward the depositional axis of the basin (Cunha et al., 2007). The age this formation is interpreted as Neoemsian-Eoeifelian (Eo-Mesodevonian) (Melo and Loboziak, 2003; Grahn and Melo, 2004; Cunha et al., 2007).

The Alter do Chão Formation lithology is characterized by its thick, variegated sandstones, and sandstones and conglomerates of facies and alluvial plain, restricted to the eastern portion of the basin. There are lateritic ferrous bands in some sand layers. The microfossil record of this stratigraphic unit is characterized only by the occurrence of palynomorphs (Dino et al., 1999). The record of macrofossils consists of leaf prints, amber and dinosaurs remains (Price, 1960; Pereira et al., 2007.). The paleoenvironment of this formation is characterized by a high energy fluvial system. The weather at the time was humid, as evidenced by the lateritic ferrous bands in some sandy levels of this stratigraphic unit and the paleodrainage influence was from east to west, toward the Pacific Ocean (Cunha et al., 2007). Despite the various lithological and faunal parameters which indicate continental paleoenvironment, Rossetti and Netto (2006), based on facies analysis and palaeoenvironment ichnology suggest that continental flows originating from a northwestern delta system progradated to the basin, and it was connected to the marine environment (Daemon and Contreiras, 1971). The deposition of this unit is interpreted as occurring between Aptian (Dino et al., 1999) and Maastrichtian (Daemon and Contreiras, 1971).

\section{Method}

The sampling activities take place in three areas determined by DNPM (Altamira, Travessão 27 area and Sítio Belo Monte) by quarterly sampling visits which last 21 days each. During these periods all three areas are inspected and the search for sampling points of fossil materials occur. A reduced team geological professionals remain on field in the intervals between field works in order to inspect the construction of Belo Monte, to ensure that no fossil material is lost.

A survey of the interest area in the search for scientifically appropriate places to perform sampling, those with thicker and in which the fossils are probably better preserved, allowed the identification of sedimentary sections the most suitable for sampling. The geological mapping of sedimentary rocks was an important step for the guidance 
of potential spots for sampling these tools to optimize fossil search. High resolution satellite images and radar along with geostatistical spatial analysis also improves punctual collect data by the use of integrated magnetic and GPR (Ground Penetration Radar) methods present itself as being of high importance in helping recognition of burried fossil concentrations, especially of invertebrates, thus directing the excavation, and directly affecting the expenditure of time and resources in the field, as well as increasing the probability of identifying fossil occurrences, as shown by Tomassi et al. (2011).

The fossiliferous sampling occurred according to the standard methods in paleontology, which are the drawing of a sedimentary column, to identify on it the stratigraphic level for every sample and protect it to prevent contamination (especially microfossils samples) and shipping damage. The sampling must cover all known fossil groups, unrestrictedly.

The macrofossils samples are protected by special, soft and disposable packaging for the transport to our logistic base and the microfossils samples were packed in plastic bags. The level of collection of each sample was identified in the stratigraphic columns. The samples were identified by the prefix $\mathrm{C} m \mathrm{P} n-x . y w$, where " $m$ " indicates the number of the field work, " $n$ " indicates the number of sampling point in the field work, " $x$ " indicates the stratigraphic level of sampling, " $y$ " indicates the piece number within level (only used at levels that contains more than one piece sampled) and " $w$ " (a letter) indicates the parts of the same fossil (used only for fossils that comprises more than one piece).

In the laboratory preparation phase, at our logistic base, the macrofossils samples were cleaned and prepared for study by the removal of rock that interferes with its description. As a method of analysis of fossil we use images acquired by tomography, which allows the optical separation of materials with different densities and three-dimensional observation of fossil in deep portions of rocks, not visible on the surface. Petrographic slides of some fossils were also built, for detailed analysis. And Micropaleontology samples were prepared for identifying carbonate, siliceous, phosphatic and organic microfossils.

All samples (macrofossils and microfossils) were finally inventoried and prepared for shipment to the institution responsible for their safeguard. The correlation of stratigraphic columns, the detailed geologic map and other relevant onformation will also be delivered to the museum. The best preserved and representative specimens were photographed and the images comprise part of unpublished technical reports submitted to Norte Energia S.A. (2011) and to DNPM.

\section{Results}

In Belo Monte site, rocks identified as belonging to Pitinga, Manacapuru, Jatapu, Maecuru and Alter do Chão and formations been exposed by the cuts of construction. The field differentiation between rocks from Manacapuru and Jatapu formations is not easy, which is why we decided to work with this sedimentary interval as just one geological set, undissociated. In this unit a fossil richness is found, characterized by the occurrence of trace fossils, possible plant remains, invertebrates, graptolites, Agnatha, microfossils and unidentified fossils. The Belo Monte paleontological salvage was able to recover 495 microfossil samples and 1744 macrofossil samples on 30 months of sampling activities, and it is still ongoing. It should be pointed out that one single macrofossil piece may have dozens of fossil specimens, such as brachiopods.

On the margins of Xingu River, in the area of Altamira, Maecuru Formation outcrops are the most abundant, and generally show lower contents of macrofossils. In this local trace fossils are the most common fossil record.

In Travessão 27 area few rocks were exposed with Belo Monte construction. Some levels have been identified as Manacapuru/Jatapu, Maecuru and Alter do Chão formations. At this site the major occurrences are brachiopods and trace fossils.

In this paper is presented some preliminary fossil specimens representing the sampled assemblage, which includes unprecedented invertebrate and vertebrates fossil fauna for Amazonas basin. However, scientific research is not part of PSPP scope, and this collection must be further studied by researchers who visit the institution where the fossils will be housed, and more material will be collected until the end of 2015. The collection sampled allows the composition of a mosaic with the necessary elements to assign, in later papers, taxonomic features which may lead to accurate species identification.

\subsection{Phytofossils}

Microfossils of vegetal origin are more abundant and appear before macrofossils in the palaeontologic record. The phytofossils and spores are remains of land plants origin and diversification. Beginning at the Middle Ordovician, spore tetrads with sporopollenin walls are reported over large geographic areas. The first safe records of terrestrial phytofossils appear only in the Middle Silurian (Gray, 1993). The Silurian represent the interval of time where majority of the lineages of land plants have diversified (Kenrick and Crane, 1997), approximately fifty million years after the occurrence of the first spores (Gray, 1993).

At Sítio Belo Monte were found impressions that seem to be very primitive land plant remains. The impressions are elongated structures not completely straight, not bifurcated and the measures vary from 2 to 3 centimeters long and 2 to 4 millimeters wide. On the extremity of some specimens there are distinct structures that resembles the sporangium (see Figure 2). In some there are what seem to be remains of organic matter. The fossils shape is quite similar to sporophyte of genus of bryophytes Anthoceros L. emend. Proskauer, 1951, nonvascular plants showing an elongated vertical structure, with a long, cylindrical sporophyte. 


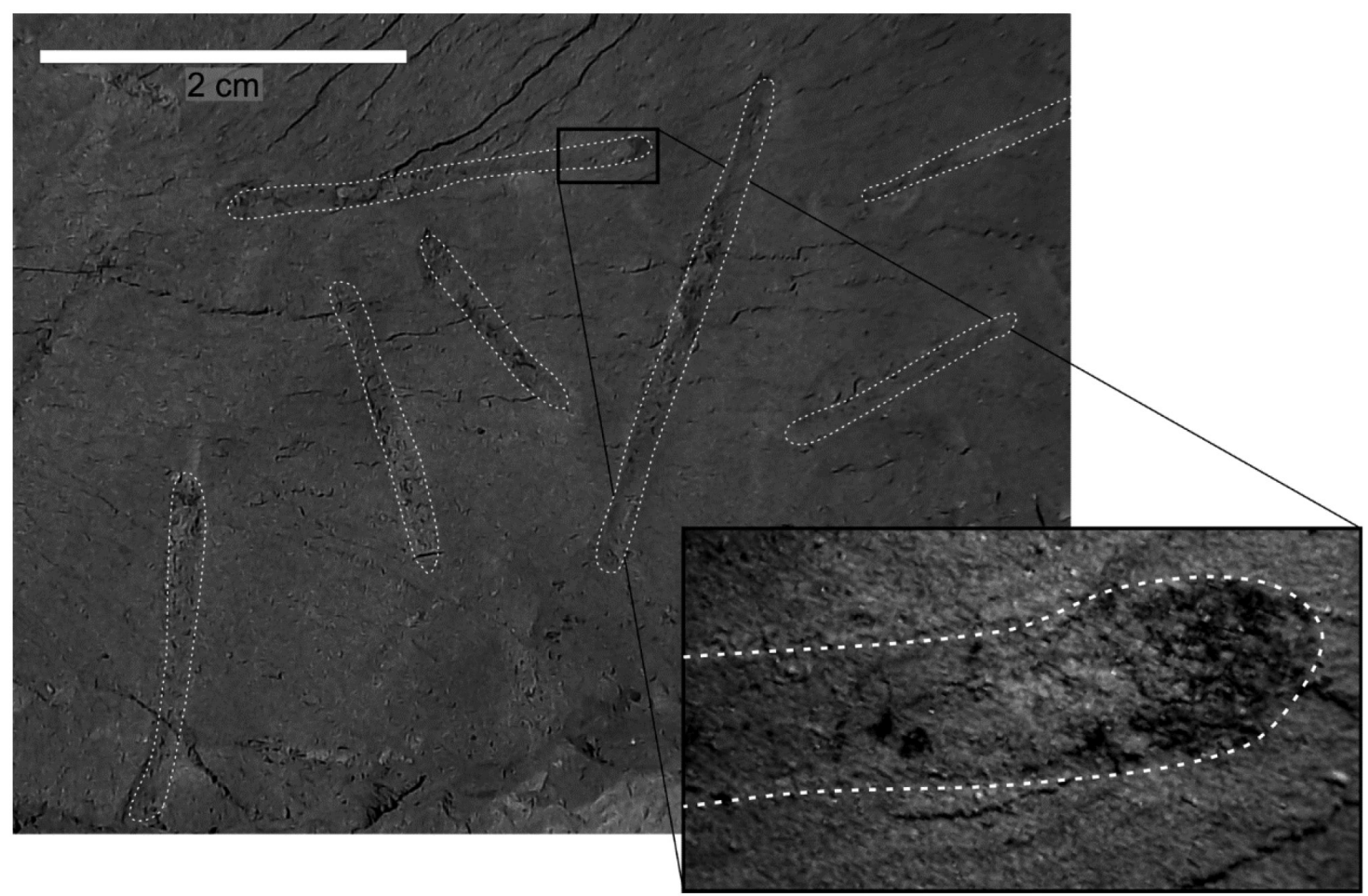

Figure 2. Possible primitive plant remains preserved as impressions, from Belo Monte, Pará State, Brazil. The detail shows organic matter on the extremity of the impressions (prefix C1P3-3.1a).

\subsection{Ichnofossils}

Traces of biological activities, preserved in various materials, are called trace fossils or ichnofossils. These forms are consistent and repetitive in sedimentary layers, so it is possible to assign it the same constructor and thus classify it as a biological genus in an artificial classification that refers to the shape of the trace left by the living being and not to the organism that produced it (Fernandes et al., 2002).

The trace fossils produced by endobionts locomotion are common in all stratigraphic columns described in the three areas covered by PSPP. There are worm tubes of various thicknesses, textures and shapes, showing that the ichnofauna recovered at the formations Pitinga, Manacapuru/Jatapu was quite diverse. The absence of fossil corporeal beings that produced these marks is probably due to the fact that skeleton was not mineralized; therefore its preservation in fossil form is hampered. They are usualy parallel to the bedding plane, in some levels are concentrated, some traces are bifurcated, sigmoidal, spiral and there are specimens of oblique bioturbations, including some which record changes of direction (see Figure 3).

Among the trace fossils of locomotion (footprints, trails, slopes, bioturbations), several genera found are described in the scientific literature. Among the genera identified, there is Palaeophycus Hall, 1847 Diplopodichnus Brady, 1947 Cochlichnus Hitchcock, 1858. There are two trace fossil which reminds Cruziana d'Orbigny, 1842, the first is probably the record of an emerging trilobite track and the second seems to be the trace of a furrowing one.

From habitation trace fossils recovered in PSPP, the highlight is for the fossil assigned as Bifungites Desio, 1940 (Figure 3). The specimens collected here are notably smaller than those described in previous papers, especially those collected in Devonian rocks in other sedimentary basins. Its average size is 1 centimeter, while the specimens previous described vary between 5 and 10 centimeters. A similar type, but with the presence of an extra node, located in the central portion of the tube as well as some specimens attributable to Gyrolites de Saporta, 1884 were also identified.

Another type of ichnofossil recorded was coprolite. The coprolites collected are characterized by spheroidal surface with nodules and streaks, probably this is the morphology of the distal portion of digestive tract of being that the produced. Another feeding icnofossil identified was Taenidium Heer, 1887.

\subsection{Brachiopods}

The fossil content analyzed is mainly composed of macroinvertebrates Phylum Brachiopoda Duméril, 1806, with the occurrence of Rhynchonellata and Lingulata groups. Overall, are well preserved, occurring to at the bedding plane or perpendicular to it. Some brachiopods are preserved with the original valves and shell. These specimens have good preservation of characters which allow precise taxonomic and taphonomic analyzes. Some strata have evidence of hydraulic flow orientation in small 

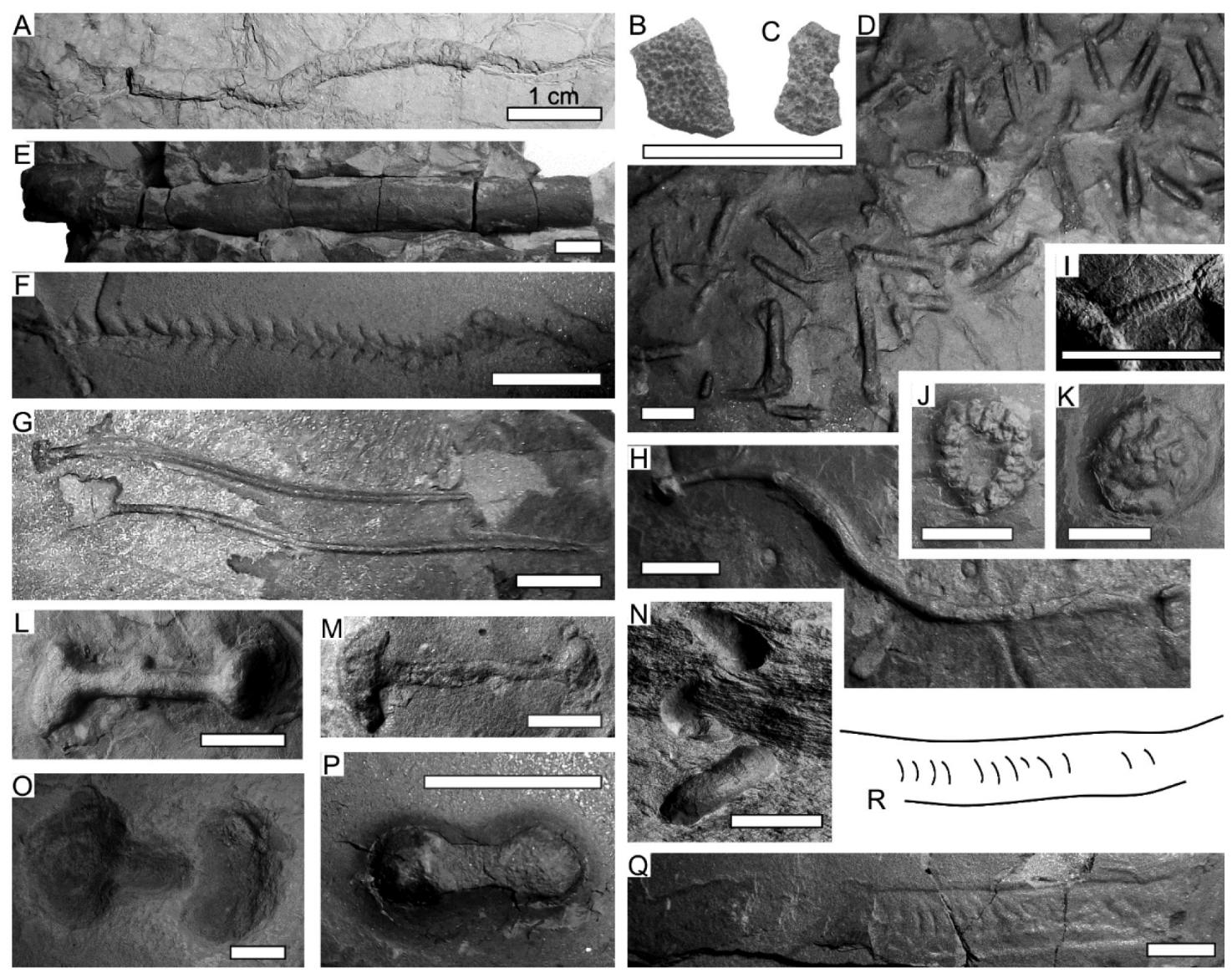

Figure 3. Most common ichnofossils from Belo Monte, Pará State, Brazil. A: Cochlichnus Hitchcock, 1858 (prefix C1P4-2.3) B: Possible reptile egg (prefix C11P3-2.2) C: possible reptile egg (prefix C11P3-2.3) D: Palaeophycus Hall, 1847 (prefix C2P4-7.2) E: Palaeophycus Hall, 1847 (prefix C10P4-4.6) F: Possible Cruziana d'Orbigny, 1842 from an emerging trilobite (prefix C2P2-7b) Diplopodichnus sp. Brady, 1947 (prefix G: C2P3-6.3a) H: Cochlichnus Hitchcock, 1858 (prefix C2P4-44a) I: Taenidium Heer, 1887(prefix C2P4-46.2) J: Coprolite (prefix C2P4-23.1a) K: Coprolite (prefix C2P4-23.7a) L: Ichnofossil similar to Bifungites, with an extra central node (prefix C2P4-R.3) M: Bifungites sp. 1 Desio, 1940 (prefix C7P4-7.3) N: Gyrolites sp. de Saporta, 1884 (prefix C3P3-10.2) O: Bifungites sp. 2 (prefix C2P3-6.12) P: Bifungites sp. 3 (prefix C2P3-21a) Q: Possible Cruziana d'Orbigny 1842 from a furrowing trilobite (prefix C6P2-6.76) R: Drawing of prefix C6P2-6.76.

channels, indicating certain transport or reorientation of some shells.

The brachiopods shells are mostly preserved with the original composition, they are preferably articulated, slightly fragmented, with fractures only in cases of mechanical breakdown in the sampling process. During data collection it was observed that when opening the layers of rocks, some were affected by dryness and fragmentation of delicate valves in contact with the atmosphere. Some fossil specimens here illustrated have been preserved through replacement of the original composition by partially or totally predominant minerals in the rocks, some demonstrate preserved body structures, internal and external, and casts. Most of the specimens preserved the structure, shape and ornamentation of the original valves. Both Lingulata and Rhynchonellata brachiopods samples include are numerous large rock plates in which taphonomic and taxonomic studies can be held.

\subsubsection{Lingulata brachiopods}

Lingulata brachiopods are the most abundant fossils in quantity and biodiversity on Siluro-Devonian outcrops studied, they dominate the fossiliferous layers and also the paleoenvironment. Recovered specimens of Lingulata brachiopods can be identified as infaunal lingulids and Orbiculoidea d' Orbigny, 1847 (see Figure 4). The collected assemblage enables to compose a mosaic with all the necessary characteristics to assign a precise taxonomy in future research.

Specimens of Orbiculoidea lack depositional fragmentation, valve separation is only due to the collection and preparation process. They have preserved ornamentation on the valves, growth lines or ribs, preserving the umbo, foramen in some specimens and rare muscle impressions.

The specimens illustrated are well preserved, abundant and in levels characterized by low biodiversity, in Silurian 

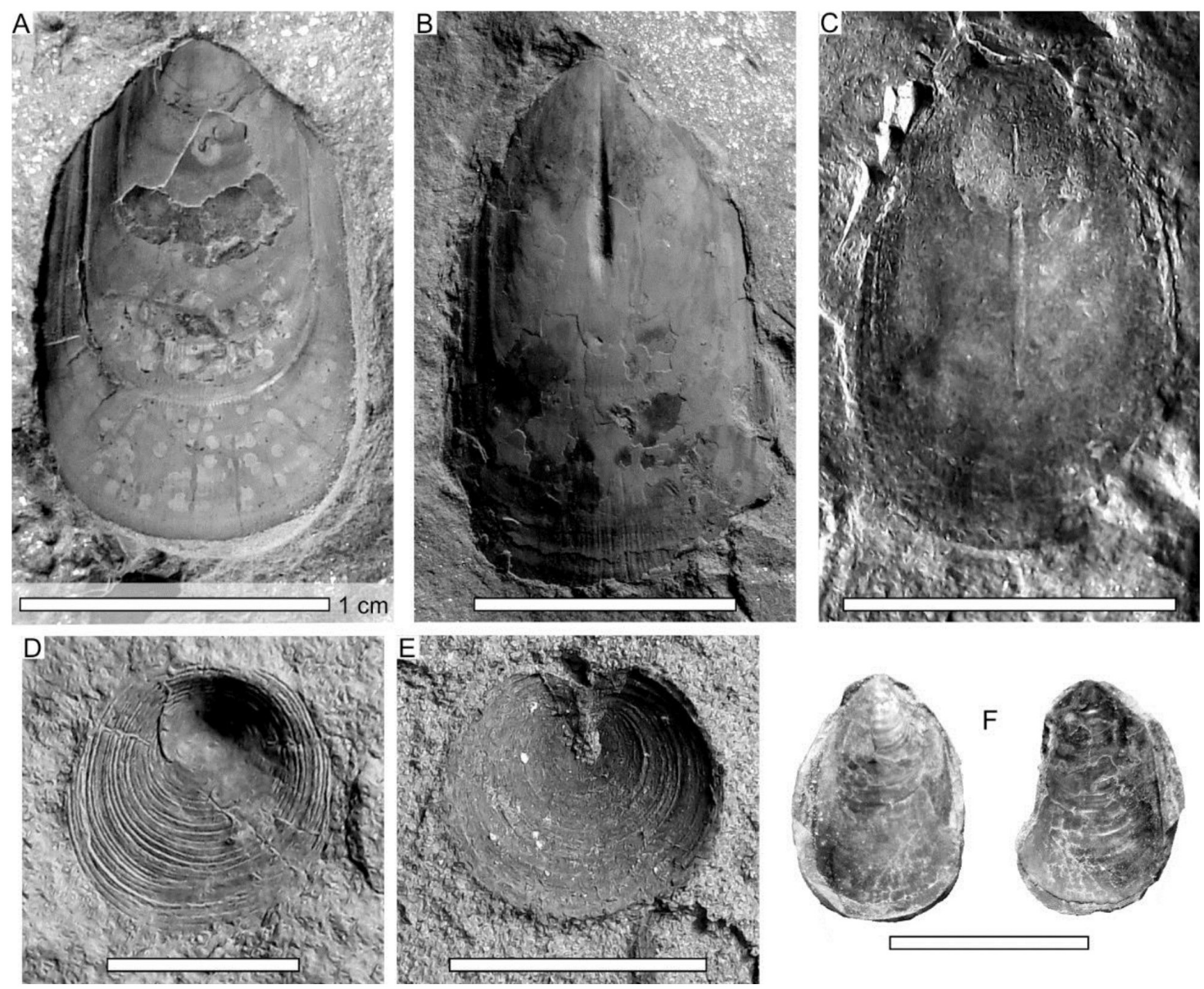

Figure 4. Lingulata brachiopod from Belo Monte, Pará State, Brazil. A-C infaunal lingulids A: ventral tridimensional valve of preserved shell (prefix C6P2-6.39a) B: dorsal tridimensional valve of preserved shell (prefix C6P2-6.50) C: dorsal valve preserved as impression (prefix C3P1-4.1b). D,E: Orbiculoidea D: dorsal tridimensional valve of preserved shell (prefix C4P6-R.1a) E: ventral tridimensional valve of oxidated shell (prefix C4P2-5.39) F: infaunal lingulid shell preserved inside a round reworked concretion (C6P3-5.328a and C6P3-5.328b).

and Devonian outcrops. The preservation of valves indicates not much postmortem transport before final sedimentation.

The occurrence of infaunal lingulids are restricted to Manacapuru/Jatapu formations at Sítio Belo Monte, by occurring with two patterns of different size, in some levels smaller specimens predominate and other levels have normal-sized shells, as also reported by Bosetti et al. (2010) at Paraná basin. The infaunal lingulids specimens size vary between 1.8 millimeters to 6 millimeters of length and 1.2 millimeters to 4 millimeters of width. Larger specimens size vary between 20 millimeters and 10 millimeters width.

\subsubsection{Rhynchonellata brachiopods}

It has been found three different morphotypes of Rhynchonellata brachiopods on the studied outcrops. They are less frequent in sedimentary strata of Belo Monte construction site than Lingulata brachiopods. At Sítio Belo Monte they were found in abundance only a few centimeters above the geologic basement, in the Manacapuru/Jatapu formations. The species identified are Paucicrura cf. rogata, a unindetified genus of Spiriferidae, Gen. et sp. 1 and Gen. et sp. 2 (see Figure 5).

\subsection{Graptolites}

Belonging to the phylum Hemicordata Fortey, 1998, Graptolites are extinct colonial animals that populated tropical oceans 320 to 540 million years ago. Their fossil record is found on all continents except Antarctica (Palmer and Rickards, 1991). Each colony is called graptolite rhabdosome. This may have one or more branches (stems), which are formed by teak, overlapping tapered structures that give the assembly a serrated appearance. The size of rhabdosome can vary from a few millimeters to over a meter long. The organization of teak and the number and arrangement of the stipes are particular of the numerous described species (Bulman et al., 1970; Benton and Harper, 2009).

Dozens of graptolites specimens were found in outcrops of Manacapuru/Jatapu formations at Sítio Belo Monte. Despite 

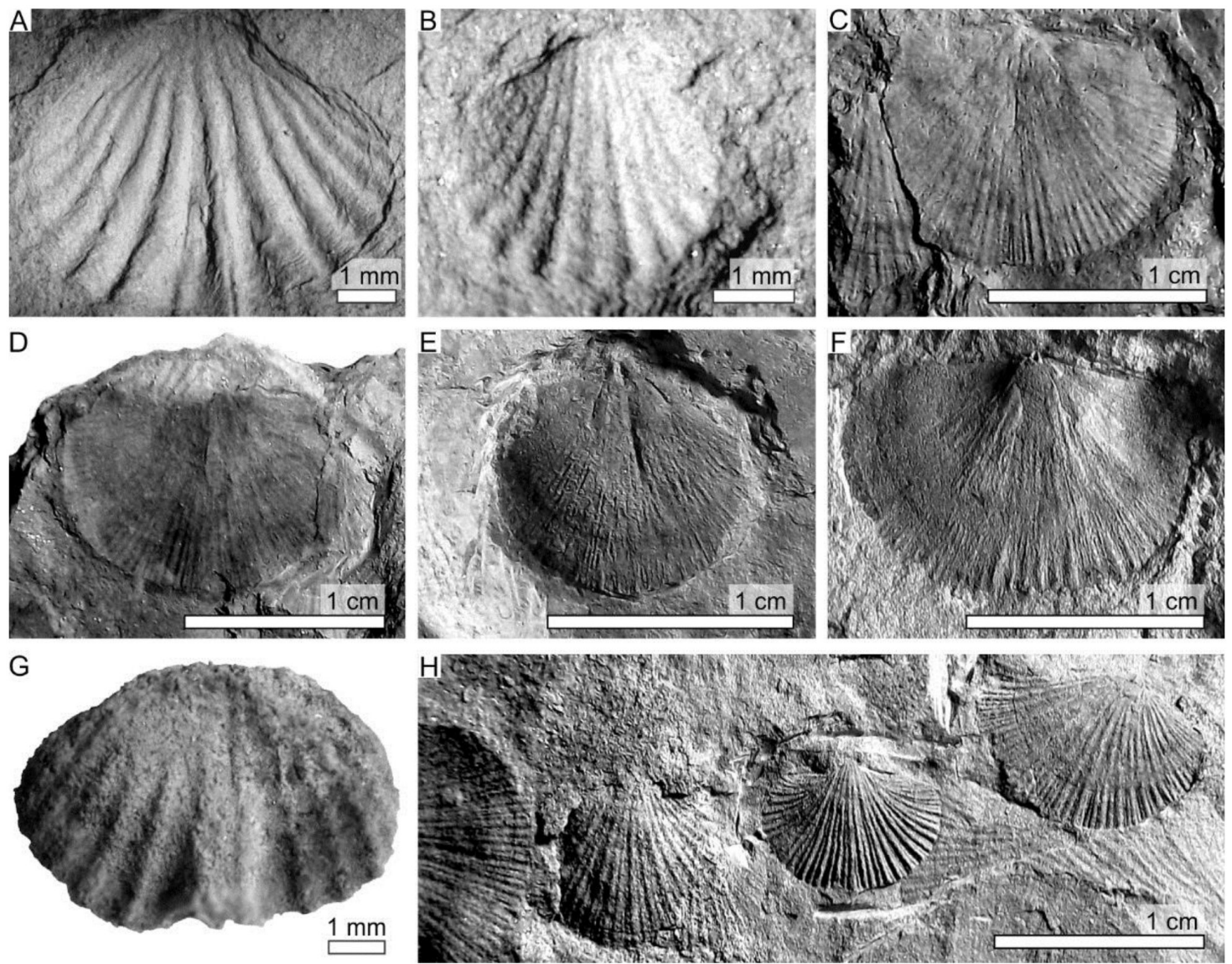

Figure 5. Undetermined Rhynchonellata brachiopods from Belo Monte, Pará State, Brazil. A: Gen. et sp. 1 (prefix C8P12-R.1a) B: Gen. et sp. 2 (prefix C4P6-3.4b) C: Possible Paucicrura rogata (prefix C4P6-3.4a) D: Possible Paucicrura rogata (prefix C4P6-3.7a) E: Possible Paucicrura rogata (prefix C3P1-1.9a) F: Possible Paucicrura rogata (prefix C3P1-4.4b) G: Spiriferidea (prefix C3P1-1.212) H: Rock plate with brachiopod shells (prefix C3P1-1.47f).

of the great number of specimens recovered it is possible to recognize only two taxa, Monograptus aff. priodon, the most abundant, and Climacograptus innotatus brasiliensis (see Figure 6). The specimens found of Monograptus aff. priodon are quite similar to those described by Uriz et al. (2008) in the Vargas Peña Formation, Paraguayan part of the Parana basin which have a narrow steam.

\subsection{Other invertebrates}

Some fossil specimens of other invertebrates were collected at Sítio Belo Monte sampling activities. Among those fossils, an isolated arthropod appendix printed on the sedimentary rock (prefix C3P2-17) is an important record (see Figure 7). In this specimen, it is possible to observe the presence of a curved end wide distal thorn, and it is ornamented in the form of eighteen spines on the distal margin of the appendix, the most distal is quite width. The size, morphology and age of the fossil in question may suggest that it is the appendix of Silurian trilobites, hypothesis reforced by the presence of trace fossils attributable to the group. Some fossil mollusks (bivalves, gastropods and cephalopods) and cnidaria were collected, but these specimens are always rare and poorly preserved.

\subsection{Agnatha}

Agnatha squamation were collected on Manacapuru/ Jatapu formations at Sítio Belo Monte. These fossils are represented by a thin film of black material, possibly with organic component, preserved in print form, flattened on bedding. The specimens of Agnatha collected in this project have noncalcified scales whose morphology varies with its position on the body surface. In the central portions they have a chevron shape, were they are larger and show a more closed angle between the bars. At the dorsal portion, the bars tend to become less visible and at the ventral portion, they tend to become rounded and flattened, until the final ventral margin were they are characterized by a circular shape, as can be seen at prefix C2P4-R.4b (see Figure 7). Several samples were collected, smaller and with less visible structures, at a number of outcrops in Sítio Belo Monte.

\subsection{Palynomorphs}

As present in the description of the geological units of Belo Monte, palynomorphs are common microfossils in rock section and its age is defined by biostratigraphy. Thirty-one selected samples were prepared for recovering 


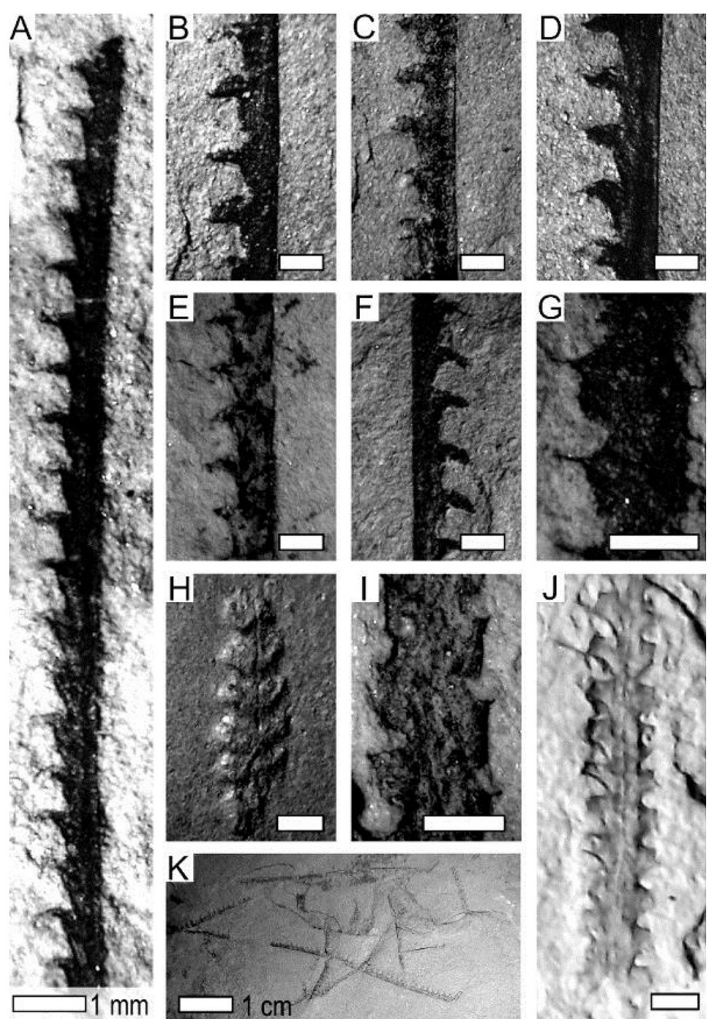

Figure 6. Graptolites from Belo Monte, Pará State, Brazil. A-G Monograptus aff. priodon A: prefix C5P4-R.2a $\mathrm{B}$ : prefix C2P2-R.3a C: prefix C2P2-1.3b D: prefix C2P2-1.9a E: prefix C5P2-14.1a F: prefix C2P2-1.3b $\mathrm{G}$ : prefix C5P2-11.2b H-J: Climacograptus innotatus brasiliensis $\mathrm{H}$ : prefix C2P3-8.2a I: prefix C3P2-14.2b J: prefix C6P5-2.2 K: Rock plate with Monograptus aff. priodon stipes (prefix C2P2-1.10a). Scale bar $=1$ milimeter, except $\mathrm{K}$, which is 1 centimeter.

carbonate, siliceous, phosphatic and organic microfossils. Only the preparation of organic resulted in the recovery of numerous microfossils. The techniques used for palynology were developed for sediments containing pollen and spores after Salgado-Labouriau (2007). As result, the palynomorphs found were identified by its similarities in their morphological characteristics as ornamentation, size and shape. It is important to point that the results shown here are preliminary, especially its taxonomy, which will be published in detail in the future, including also more biostratigraphic and paleoenvironmental considerations.

The palynological analysis of 24 sediment types comprising 8 miosphore, 5 acritarchs, 5 fungi, 3 algae and 3 unidentified were recorded. Pollen grain of angiosperms, comprising two types one being represented by Poaceae were found, which are probably due to contamination during sampling stage. The total number of registered palynomorphs was 420 grains, including miosphores, acritarchs, algae cysts, fungi spores and unidentified types (see Figure 8).

The distribution of palynomorphs did not occur homogeneously in the samples. Although the total number of registered miosphores is 61 and acritarchs is 104 this type of distribution result, in most of the samples, in a wide number of samples with low diversity, often with the concentration of a single type in the sample, which impedes the establishment of a characteristic assemblage biozones and correlation with an already established assemblage such as Melo and Loboziak (2003), Steemans et al. (2008) and Cardoso (2005). The only level with higher diversity recorded a total of 39 palynomorphs, with 06 miosphores distributed among 4 types, 7 acritarchs with 4 types, 18 cysts of a single type of algae and 7 fungi distributed among 2 types.

\subsection{Unidentified fossils}

As the presented taxonomy is preliminary, because the paleontologic salvage is focused mainly on exhaustive sampling, the bibliographic research realized, at first it was not found fossil group with the same characteristics observed in these fossils. Thus, it was grouped a set of fossils that have peculiar characteristics and identification are still indeterminated. Morphotypes identified may correspond to integral or fragmented invertebrates as well as trace fossils and the specimens here illustrated are just a few of which were recovered by PSPP.

The specimens prefixed as C7P4-15.1a, C7P4-15.b, and samples $\mathrm{C} 2 \mathrm{P} 2-29 \mathrm{a}$ and $\mathrm{C} 2 \mathrm{P} 3-5.28$, among others, seems to be quite similar to a crinoid, but the portion corresponding calyx has no calycine plates (see Figure 9). The stalk is formed by sequence of interconnected spheres that alone would resemble ichnogenus Hormosiroidea Schaffer, 1928. Other different feature is the presence of a kind of thin cone-shaped capsule, which involves the whole fossil.

For the fossil C7P4-2.2a and C2P2-R.9b is similar to Conularia amazonica Clarke, 1897, but it does not share the typical conularia shape with four prominently-grooved corners. This is a big cone-shaped laterally flattened fossil, with transverse streaks to the longer axis.

Specimens characterized by thin, conical shape, elongated deformed skeleton targeted by septa and/or growth lines which form chambers, located transversely to the growth axis of the series (C2P3-5.27a, C2P2-5.1a). The specimens resemble Tentaculites trombetensis Clarke, 1897, in general shape, but have also similarities with orthoconic cephalopods, or type Ctenoceras Noetling, 1884, Archigeisonoceras Chen, 1984 and, most likely Spyroceras Hyatt, 1884.

The specimens C2P2-R.5b and $-\mathrm{C} 2 \mathrm{P} 2-11.1 \mathrm{~b}$ are impressions with poor preservation, and the occurrence of a few specimens not allow an identification taxonomic. These are some fossils specimens that have been collected and require further study which compare similarities with common fossil groups.

\section{Age Discussion}

Palinoporph analysis of Sítio Belo Monte sequence made possible to suggest a cronology from the comparison with other papers describing organic microfossils in the Amazonas basin (Melo and Loboziak, 2003; Steemans et al., 


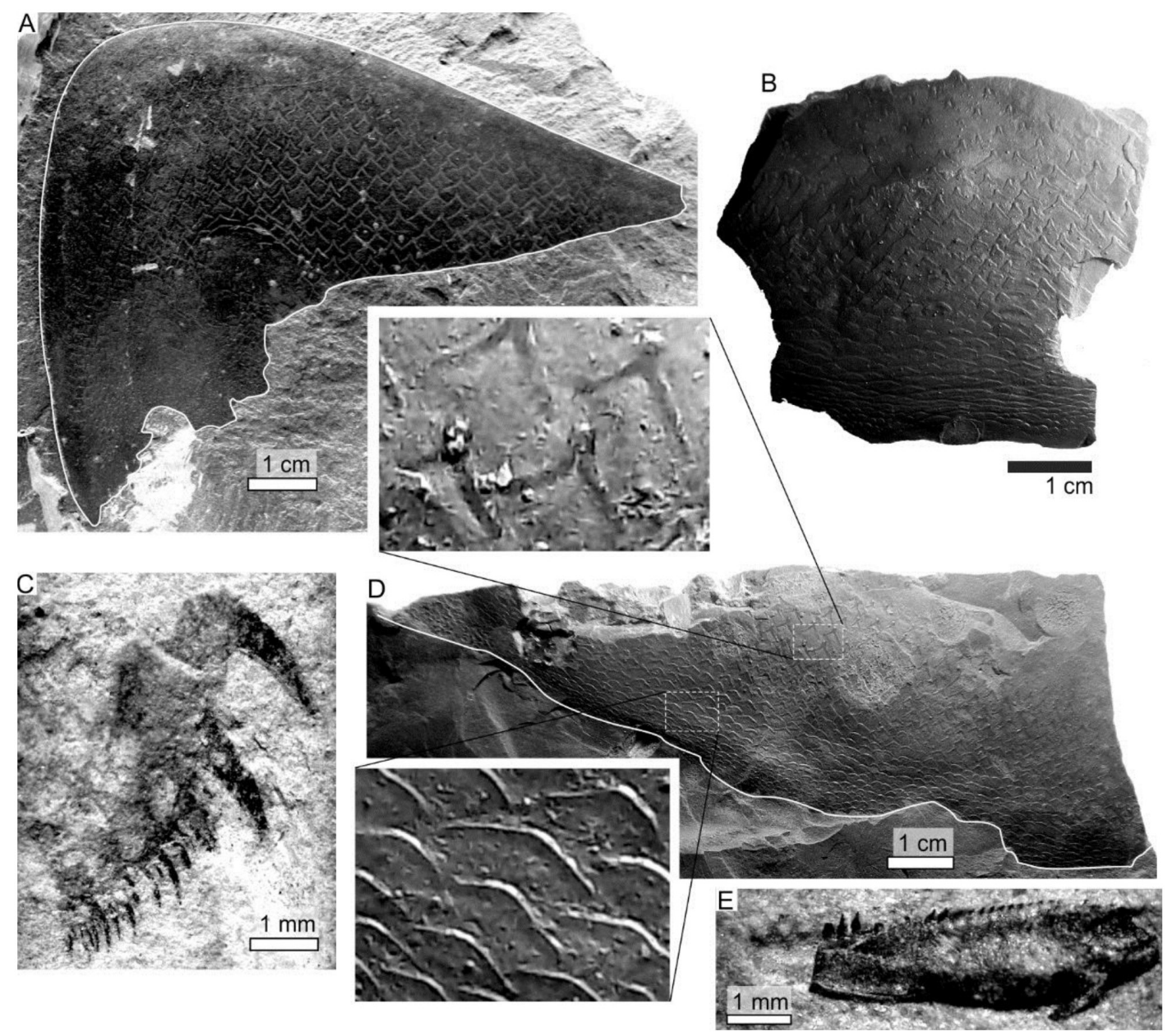

Figure 7. Agnatha squamation and arthropods from Belo Monte, Pará State, Brazil. A: Agnatha squamation (prefix C2P4-36a) B: Agnatha squamation (prefix C2P4-R.4b) C: Arthropod appendage (prefix C3P2-17) D: Agnatha squamation (prefix C2P4-R.2b) E: Arthropod appendage (prefix C6P2-4.1a).
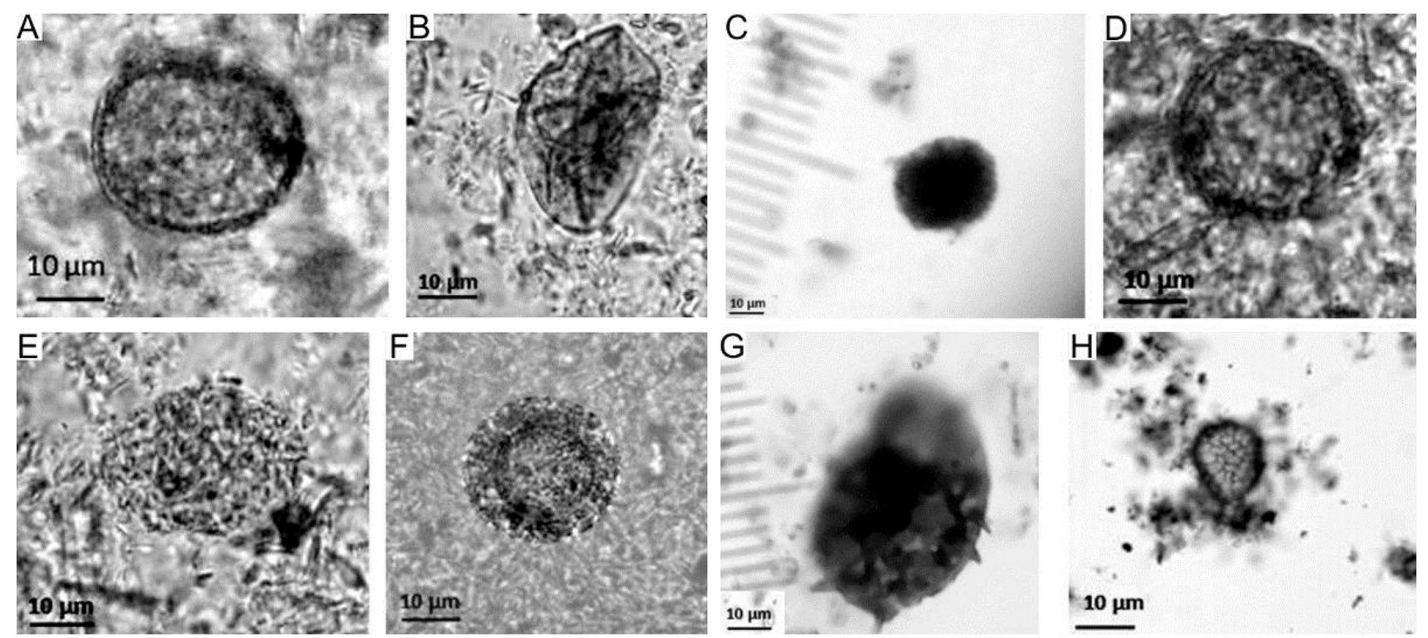

Figure 8. Palinomorphs from Belo Monte, Pará State, Brazil. A: Geminospora sp. B: Ambitisporites avitus Morphon (Hoffmeister 1959) Steemans et al., 2008 C: Perotrilites tessellatus (Staplin) Neville, 1973 D: Perforela perforata Diez \& Cramer, 1976 E: Chelinospora cassicula Richardson and Lister, 1969 F: Duvernaysphaera actinota Loeblich \& Wicander, 1976 G: Visbysphaera sp. H: Dictyotriletes cf. subgranifer McGregor, 1973. 

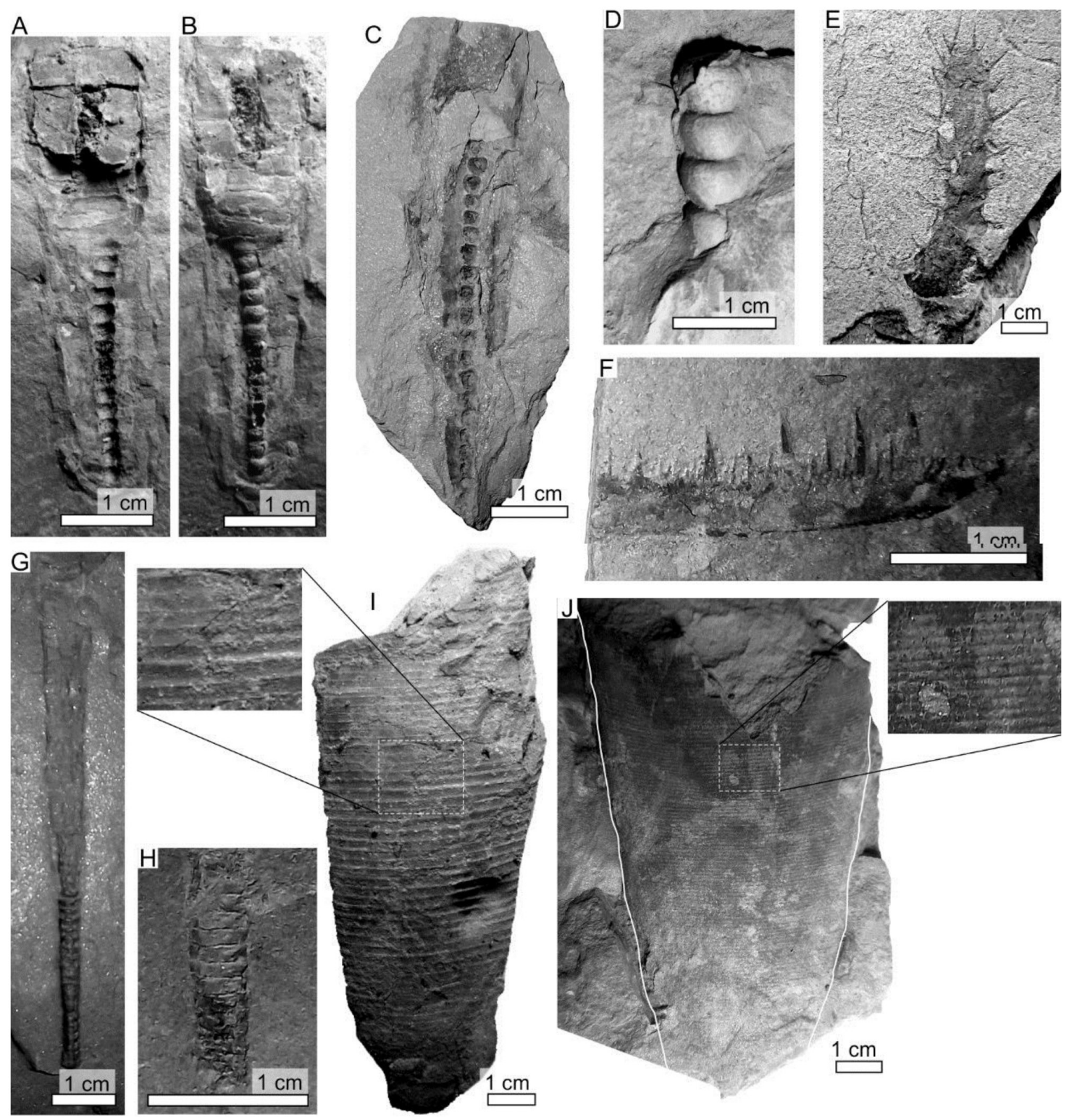

Figure 9. Unidentified fossils from Belo Monte, Pará State, Brazil. A: prefix C7P4-15.1a B: prefix C7P4-15.1b C: prefix C2P2-29a D: prefix C2P3-5.28 E: prefix C2P2-R.5b F: prefix C2P2-11.1b G: prefix C2P3-5.27a H: prefix C2P2-5.1a I: prefix C7P4-2.2a J: prefix C2P2-R.9b.

2008; Cardoso, 2005). Thus, in agreement with the identified types, some levels record the presence of perforata Perforela and Visbysphaera sp. (Rubinstein et al., 2008), according to Cardoso (2005), it is indicative of Silurian age. There is also the record of Perotrilites sp, Duvernaysphaera actinota (Rubinstein, et al., 2008) and indicative Perforela perforata, which corroborate Late Silurian and Early Devonian ages for some layers (Steemans et al., 2008; Cardoso, 2005). The occurrence of Ambitisporites avitus (Steemans et al., 2008), Chelinospora cassicula (Melo and Loboziak, 2003) and Dictyotriletes cf. Subgranife (Melo and Loboziak, 2003) suggest the age of early Devonian for some beds.
Due to their richness, diversity and wide distribution, the graptolites are also considered an important tool for stratigraphic correlation around the world and due to its gradual morphological evolution over geologic time, they are also excellent fossil guides (Palmer and Rickards, 1991; Fortey, 1998). The section-type of the Trombetas Group in Trombetas River has a fauna dominated by Climacograptus innotatus brasiliensis, dated as Lower Silurian. However, there was the presence of Monograptus sp. cf. M. gregarius, indicating Medium Landoverian (Grahn, 1992). The Graptolites recovered by PSPP also corroborate the age established for the levels which they were found. 
The earliest records of vertebrates in the Amazonas basin are reported for Manacapuru Formation (Janvier and Melo, 1988, 1992), thus the occurrence of Agnatha squamation may represent the earliest record in Brazil for this group of vertebrates. Similarly, the genus Bifungites, despite the scientific literature report it in Lower Cambrian to Carboniferous strata (Fernandes et al., 2002), it has all of his occurrences in Brazil restricted to Devonian and Permian. The sampling of these trace fossils on Sítio Belo Monte may be the oldest Bifungites specimen found in Brazil.

\section{Conclusions}

The Belo Monte paleontological salvage was able to recover 495 microfossil samples and 1744 macrofossil samples on 30 months of sampling activities, and it is still ongoing. The collection recovered by this program is a vast material of various fossil groups, sampled according to criteria that ensure its scientific use. Assuming that marine Silurian deposits in other Brazilian basins is unrepresentative regard to fossils preservation, through this paleontology mitigation work, the Silurian in the Amazon Basin has become a reference for the study of fossils of this period in Brazil and Southern Hemisphere, especially in the field of trace fossils and brachiopods.

The fossil quantity, quality and diversity sampled by PSPP shows how many relevant material can be recovered by mitigation paleontology to be examined on future research.

The ichnofossil sampling in large numbers is relevant for the understanding of the past ecosystem due to the fact that they are the only records available for the study of living beings who have left no other fossil forms, especially those devoid of skeletal remains, and because they are practically the only fossil from which you can deduce the behavior of the beings of the past, since they are produced by their activities.

Future analyzes of the entire fossil collection collected by PSPP will allow the accurate development of taxonomy, biostratigraphy and palaeoecology for the lower units of the Amazon basin. Among the contributions of the program, which is still in progress, it stands for the availability of aplenty well preserved specimens and for the study of some unpublished fossils, such as Agnatha squamation and the unidentified fossils.

\section{Acknowledgements}

The first author wish to thank Raoul J. Mutter for the identification of Agnatha squamation and also the anonymous referee for the contribution and reference indications.

\section{References}

BENTON, MJ. and HARPER, DAT., 2009. Introduction to paleobiology and the fossil record. Hoboken: Wiley-Blackwell. $608 \mathrm{p}$.

BOSETTI, PE., HORODYSKI, RS., ZABINI, C., MATSUMURA, WMK. and PENTEADO, AC., 2010. Ocorrência de fenótipos subnormais no limite Eoeifeliano/Eogivetiano, Tibagi, estado do Paraná: implicações tafonômicas e paleossinecológicas. Boletim Museu Paraense Emílio Goeldi. Ciências Naturais, vol. 5, no. 2, p. 135-149.

BULMAN, OMB., MOORE, RC. and TEICHERT, C., 1970. Treatise on invertebrate paleontology, Part V: Graptolithina: with sections on Enteropneusta and Pterobranchia. 2nd ed. Boulder: Geological Society of America. $195 \mathrm{p}$.

CARDOSO, TRM., 2005. Acritarcos do siluriano da bacia do Amazonas: bioestratigrafia e geocronologia. Arquivos do Museu nacional, vol. 63, no. 4, p. 727-759.

CLARKE, JM., 1899. A fauna siluriana superior do Rio Trombetas. Archivos do Museu Nacional, vol. 10, p. 1-48.

CUNHA, PRC., MELO, JHG. and SILVA, OB., 2007. Bacia do Amazonas. Boletim de Geociências da Petrobras, vol. 15, p. $227-251$

DAEMON, RF. and CONTREIRAS, CJA., 1971. Zoneamento palinológico da Bacia do Amazonas. In Anais do $25^{\circ}$ Congresso Brasileiro de Geologia, 1971. São Paulo. São Paulo: Sociedade Brasileira de Geologia. vol. 3, p. 79-88.

DINO, R., SILVA, OB. and ABRAHÃO, D., 1999. Caracterização palinológica e estratigráfica dos estratos cretáceos da Fm. Alter do Chão, Bacia do Amazonas. In Anais do $5^{\circ}$ Simpósio Sobre o Cretáceo do Brasil, 1999. Rio Claro. Rio Claro: Sociedade Brasileira de Geociências. p. 557-565.

FERNANDES, ACS., BORGHI, L., CARVALHO, IS. and ABREU, CJ., 2002. Guia dos Icnofósseis de Invertebrados do Brasil. Rio de Janeiro: Editora Interciência. 260 p

FORTEY, RA,. 1998. Life: a natural history of the first four billion years of life on earth. New York: Alfred A. Knopf. p. 129.

GRAHN, Y. and MELO, JHG., 1990. Bioestratigrafia dos quitinozoários do Grupo Trombetas nas faixas marginais da Bacia do Amazonas. Rio de Janeiro: PETROBRAS/CENPES/DIVEX/ SEBIPE. 43 p. Report produced for the Eletrobras Eletronorte

GRAHN, Y. and MELO, JHG., 2004. Integrated Middle Devonian chitinozoan and miospore zonation of the Amazonas Basin, northern Brazil. Revue de Micropaleontologie, vol. 47, no. 2, p. 71-85. http://dx.doi.org/10.1016/j.revmic.2004.03.001

GRAHN, Y., 1992. Revision of Silurian and Devonian Strata of Brazil. Palynology, vol. 16, no. 1, p. 35-61. http://dx.doi.org/10 $.1080 / 01916122.1992 .9989406$.

GRAHN, Y., 2005. Silurian and Lower Devonian chitinozoan taxonomy and biostratigraphy of the Trombetas Group, Amazonas Basin, northern Brazil. Bulletin of Geosciences, vol. 80, p. 245-276.

GRAHN, Y., 2006. Ordovician and Silurian chitinozoan biozones of Western Gondwana. Geological Magazine, vol. 143, no. 4, p. 509-529. http://dx.doi.org/10.1017/S001675680600207X.

GRAY, J., 1993. Major Paleozoic land plant evolutionary bioevents. Palaeogeography, Palaeoclimatology, Palaeoecology, vol. 104, no. 1-4, p. 153-169. http://dx.doi.org/10.1016/00310182(93)90127-5.

JANVIER, P. and MELO, JHG., 1988. Acanthodian fish remains from the Upper Silurian or Lower Devonian of the Amazon Basin, Brazil. Palaeontology, vol. 31, p. 771-777.

JANVIER, P. and MELO, JHG., 1992. New acanthodian and chondrichthyan remains from the Lower and Middle Devonian 
of Brazil. Neues Jahrbuch für Geologie und Paläontologie. Monatshefte, vol. 4, p. 193-206.

KENRICK, P. and CRANE, PR., 1997. The origin and early evolution of plants on land. Nature, vol. 389, no. 6646, p. 33-39. http://dx.doi.org/10.1038/37918.

MELO, JHG. and LOBOZIAK, S., 2003. Devonian: early carboniferous miospore bioestratigraphy of the Amazon Basin, northern Brazil. Review of Palaeobotany and Palynology, vol. 124 , no. 3-4, p. 131-202. http://dx.doi.org/10.1016/S00346667(02)00184-7.

Norte Energia S.A., 2011. Index of hidrelétricas Belo Monte: relatórios semestrais. Brasília: Norte Energia. Available from: $<$ http://licenciamento.ibama.gov.br/Hidreletricas/Belo\%20Monte/ Relatorios\%20Semestrais/>. Access in: 21 Sept. 2015.

PALMER, D. and RICKARDS, B., (Eds.), 1991. Graptolites: writing in the rocks. Suffolk: Boydell Press. $182 \mathrm{p}$.

PEREIRA, R., CARVALHO, IS., AZEVEDO, DA. and FERNANDES, ACS., 2007. Ocorrências de âmbar nas bacias sedimentares brasileiras: uma revisão. In CARVALHO, IS. (Org.). Paleontologia: cenários de vida. Rio de Janeiro: Editora Interciência. vol. 1, p. 243-256.

PONCIANO, LCMO. and MACHADO, DMC., 2007a. Hábitos de vida da associação Schuchertella agassizi - Pthychopteria eschwegei, Formação Maecuru, Devoniano, Bacia do Amazonas, Brasil. Anuário do Instituto de Geociências, vol. 30, p. 129-138.

PONCIANO, LCMO. and MACHADO, DMC., $2007 \mathrm{~b}$. Macroinvertebrados da Formação Maecuru (Devoniano, Bacia do Amazonas, Brasil): considerações tafonômicas. In CARVALHO, IS. (Org.). Paleontologia: cenários de vida. Rio de Janeiro: Editora Interciência. vol. 1, p. 131-137.

PONCIANO, LCMO., 2010. Fósseis devonianos da Bacia do Amazonas: paleoautoecologia dos macroinvertebrados da formação Maecuru. Trindade: Editora Bookess. 138 p.

PONCIANO, LCMO., MACHADO, DMC., FARIA, ACG. and VIEIRA, ACM., 2007a. Hábitos de vida dos Gastropoda e Bellerophontida da Formação Maecuru, Devoniano Médio, Bacia do Amazonas, Brasil. Anuário do Instituto de Geociências, vol. 30, p. 191-197.

PONCIANO, LCMO., MACHADO, DMC., SOUZA, AR., FARIA, ACG. and VIEIRA, ACM., 2007b. Hábitos de vida da associação mucrospirifer katzeri - Ptychopteria eschwegei, Formação Maecuru (Devoniano), Bacia do Amazonas, Brasil. In CARVALHO, IS. (Org.). Paleontologia: cenários de vida. Rio de Janeiro: Editora Interciência. vol. 1, p. 139-148.

PONCIANO, LCMO., MACHADO, DMC., FARIA, ACG., VIEIRA, ACM., SOUZA, AR. and LIMA, KP., 2008. Paleoautoecologia dos Brachiopoda da associação Schuchertella Agassizi - Ptychopteria Eschwegei, Formação Maecuru, Devoniano Médio da Bacia do Amazonas. In Anais da Coletânea de Trabalhos Completos do $43^{\circ}$ Congresso Brasileiro de Geologia, 2008. Aracajú. Salvador: SBG. p. 854-859.

PRICE, LI., 1960. Dentes de Therapoda num testemunho de sonda no Estado do Amazonas. Anais da Academia Brasileira de Ciencias, vol. 32, p. 79-84.

ROSSETTI, DF. and NETTO, RG., 2006. First evidence of marine influence in the Cretaceous of the Amazonas Basin, Brazil. Cretaceous Research, vol. 27, no. 4, p. 513-528. http://dx.doi. org/10.1016/j.cretres.2005.10.014.

RUBINSTEIN, CV., LE HERISSE, A. and STEEMANS, P., 2008. Lochkovian (Early Devonian) acritarchs and prasinophytes from the Solimões Basin, northwestern Brazil. Neues Jahrbuch für Geologie und Paläontologie - Abhandlungen, vol. 249, p. 167-184.

SALGADO-LABOURIAU, ML., 2007. Critérios e técnicas para o quaternário. São Paulo: Edgard Blücher. 387 p.

STEEMANS, P., RUBINSTEIN, C. and MELO, JHG., 2008. Siluro-Devonian miospore biostratigraphy of the Urubu River area, western Amazon Basin, northern Brazil. Geobios, vol. 41, no. 2, p. 263-282. http://dx.doi.org/10.1016/j.geobios.2007.06.003.

TOMASSI, HZ., FERREIRA, BC., LEITE, FPR., GAMA-JÚNIOR, JM. and SILVA, MA. and CORREA, PM., 2011. Análise espacial aplicada à pesquisa paleontológica de afloramento, apoiada por métodos geofísicos. In Anais do $22^{\circ}$ Congresso Brasileiro de Paleontologia, 2011. Natal: Caicó: EDUFRN. p. 119-122.

URIZ, NJ., ALFARO, MB. and GALEANO-INCHAUSTI, JC., 2008. Silurian (Llandovery) monograptids from the Vargas Peña Formation (Paraná Basin, Eastern Paraguay). Geologica Acta, vol. 6 , no. 2, p. 181-190.

WANDERLEY FILHO, JR., MELO, JHG., FONSECA, VMM. and MACHADO, DMC., 2005. Bacias sedimentares brasileiras: bacia do Amazonas. Phoenix, no. 82, 6 p. 